\title{
Diskriminasi Muslim dalam Birokrasi Studi pada Pemerintahan Kota Jayapura
}

\author{
Suparto Iribaram, Irwan Abdullah \& Ulung Pribadi \\ STAIN Al Fatah Jayapura, Universitas Gadjah Mada Yogyakarta, \\ Universitas Muhammadiyah Yogyakarta
}

\begin{abstract}
This article explains the phenomena of discrimination of Papuan Muslims in the local government in Jayapura Municipality of Papua. In the practice of bureaucracy especially the determination of officials, Papuan Muslims are not involved, even though they are indigenous Papuans. Conditions provide an explanation that there are problems that accompany Muslim travel in Jayapura. This study finds out that of the total 43 units of Regional Working Units (SKPD) which 5 are led by Muslims, while non-Muslims lead others. This composition is unequal of the population in this region, which has a 45\% proportion of Protestants and, 41\% of Muslims. This paper emphasizes three important points: first, special autonomy for Papua not only affects how regional sentiments are strengthened, but also impacts the treatment of particular groups, especially Muslims. Second, the determination of office in the government is strongly influenced by the similarity of primordial identity, especially ethnicity and religion. Third, from some positions held by Muslims, none of them are from Papuan Muslims.
\end{abstract}

\begin{abstract}
Abstrak
Artikel ini menjelaskan mengenai diskriminasi Muslim Papua dalam birokrasi pemerintahan di Kota Jayapura Papua. Dalam praktik birokrasi khususnya penentuan pejabat, Muslim Papua tidak dilibatkan, meskipun mereka merupakan penduduk asli Papua. Kondisi memberikan penjelasan bahwa terdapat persoalan yang mengiringi perjalanan Muslim di Jayapura. Studi ini menemukan bahwa dari keseluruhan Satuan Kerja Perangkat Daerah (SKPD) yang berjumlah 43, sebanyak 5 dipimpin oleh Muslim, sedangkan yang lain dipimpin oleh non-Muslim. Hal ini sangat tidak sebanding dengan komposisi penduduk di daerah ini yang memiliki perimbangan $45 \%$ Protestan dan $41 \%$ Muslim. Tulisan ini menegaskan tiga hal penting, pertama, otonomi khusus bagi Papua tidak hanya berdampak pada bagaimana sentimen kedaerahan semakin menguat, tetapi juga memberikan dampak pada perlakuan terhadap kelompok tertentu, khususnya Muslim. Kedua, penentuan jabatan di lingkungan pemerintahan sangat kuat dipengaruhi oleh kesamaan identitas primordial khususnya etnis dan agama. Ketiga, dari beberapa jabatan yang jabat oleh Muslim, tidak ada satu pun dari mereka yang berasal dari orang Papua Muslim.
\end{abstract}

\section{Kata Kunci: diskriminasi, Muslim Papua, birokrasi, Jayapura}

Author correspondence

Email: damiribar@gmail.com

Available online at http://journal.iaingorontalo.ac.id/index.php/au/index 


\section{A. Pendahuluan}

Kota Jayapura saat ini, selain dihuni oleh orang-orang yang berasal dari Papua (baik pegunungan maupun pantai) juga dihuni oleh orang-orang yang berasal dari luar seperti Jawa, Bugis, Buton, Makassar, Sumatera, Kalimantan, Bali, NTT, Aceh, Ambon, dan Kei. ${ }^{1}$ Mereka (orang yang berasal dari luar Papua) telah mengubah wajah Jayapura selama beberapa dekade ini. Banyak perubahan mendasar yang terjadi, seperti pengenalan budaya luar bagi orang Papua dan imitasi terhadap pola hidup orang-orang pendatang. Para pendatang yang berasal dari berbagai daerah tersebut memiliki motif utama yaitu motif ekonomi, artinya mereka datang untuk memenuhi kebutuhan ekonominya. Setelah beberapa lama, mereka pun berhasil mewujudkan harapan untuk aktif di bidang ekonomi. Dengan kualitas yang dimiliki, mereka mampu mendominasi bidang-bidang tertentu khususnya pendidikan dan ekonomi. ${ }^{2}$

Arus masuk ke Papua khususnya ke Jayapura telah berlangsung sejak Orde Baru melalui program transmigrasi. Umumnya, transmigran berasal dari pulau Jawa. Selain melalui program trasmigrasi ini, arus orang masuk ke Papua juga terjadi melalui proses informasi dari orang per-orang, artinya tidak direncanakan dalam skema pemerintah seperti program transmigrasi. Dampak gelombang migrasi ini selain mempengaruhi pola hubungan penduduk, yaitu antara penduduk asli dengan penduduk pendatang, juga mengubah demografi khususnya kondisi penduduk berdasarkan agama. Komposisi antara orang asli Papua dengan pendatang pun mulai berubah dan juga jumlah penduduk Muslim mulai bertambah. Sebab, diakui bahwa para pendatang adalah Muslim. Komposisi pendudu kebrdasarkan agama memang tidak menyisakan masalah, tetapi pada kondisi tertentu hal tersebut berdampak pada banyak hal termasuk keterwakilan kelompok agama dalam sebuah birokrasi pemerintahan seperti yang terjadi di kota Jayapua.

\footnotetext{
${ }^{1}$ Anthonius Ayorbaba. The Papua Way: Dinamika Konflik Laten dan Refleksi 10 Tahun Otsus Papua. Papua: Tabloid Perempuan Papua-The Papuan Institute and Institute for Indonesian Local Policy Studies (IIpos), 2011. h. 60.

2 Yakobus Perviddya Solossa. Otsus Papua Mengangkat Martabat Rakyat Papua di dalam NKRI. Jakarta: Sinar Harapan, 2005. h. 107.
} 
Menurut data yang diperolah dari kantor Kementerian Agama Kota Jayapura pada tahun 2009, penganut agama yang berada di wilayah ini terdiri dari Kristen 113.314 jiwa, Katolik 43.248 jiwa, Islam 94.953 jiwa, Hindu 2.495 jiwa, Budha 1.927 jiwa. Dari komposisi penduduk menurut penganut agama, maka dapat disimpulkan bahwa penduduk Kota Jayapura mayoritas penganut agama Kristen. Berdasarkan data tahun 2010, dalam konteks Jayapura, pemeluk Islam menduduki posisi terbesar kedua dengan jumlah 70.072 jiwa atau 45,05\% dari total penduduk yang berjumlah 155.548 jiwa. Posisi pertama masih diduduki pemeluk Kristen dengan jumlah 75.288 jiwa atau $48.40 \%$. Posisi ketiga adalah pemeluk Katolik sebesar 8.968 jiwa atau 5,77 \%. Pemeluk Islam (Muslim) didominasi oleh pendatang dengan jumlah 121.837 jiwa dan penduduk Muslim asli sebanyak 4.958 jiwa. Sedangkan pemeluk Kristen dan Katolik dari penduduk asli sebesar 149. 272 jiwa, pemeluk Kristen dan Katolik pendatang sebesar 62.996 jiwa. ${ }^{3}$ Adapun data terakhir yang diperoleh menunjukkan tren yang relatif sama, di mana pemeluk Protestan masih menduduki posisi teratas. Data tahun 2016 yang diperoleh peneliti masih menunjukkan kecenderungan yang sama, artinya pemeluk Prostestan masih menjadi terbanyak di Kota Jayapura. Pada tahun 2016 sebagaimana yang dilansir oleh Kantor BPS Kota Jayapura menggambarkan bahwa pemeluk Protestan berjumlah 383.493 jiwa, Muslim kemudian berada pada urutan kedua sebanyak 254.100 jiwa, Katolik sebanyak 84.474 jiwa, Budha sebanyak 2.370 jiwa, dan Hindu sebanyak 2097 jiwa.

Jumlah tersebut tersebar ke dalam 5 (lima) distrik atau kecamatan di wilayah Kota Jayapura, yaitu Abepura, Muara Tami, Heram, Jayapura Utara, dan Jayapura Selatan. Komposisi penduduk berdasarkan agama ini tidak lepas dari adanya migrasi besar-besaran dari luar Kota Jayapura sehingga munculnya anggapan adanya Islamisasi dan Kristenisasi di Kota Jayapura dalam beberapa konteks menjadi sangat kompleks. Secara prosentase, komposisi penduduk berdasarkan agama pada tahun 2016 dapat dilihat sebagaimana gambar berikut.

\footnotetext{
3 Agus Indiyanto (ed.). Agama di Indonesia dalam Angka: Dinamika Demografis Berdasarkan Sensus Penduduk tahun 2000 dan 2010. Yogyakarta: CRCS UGM, 2013. h. 14-15.
} 


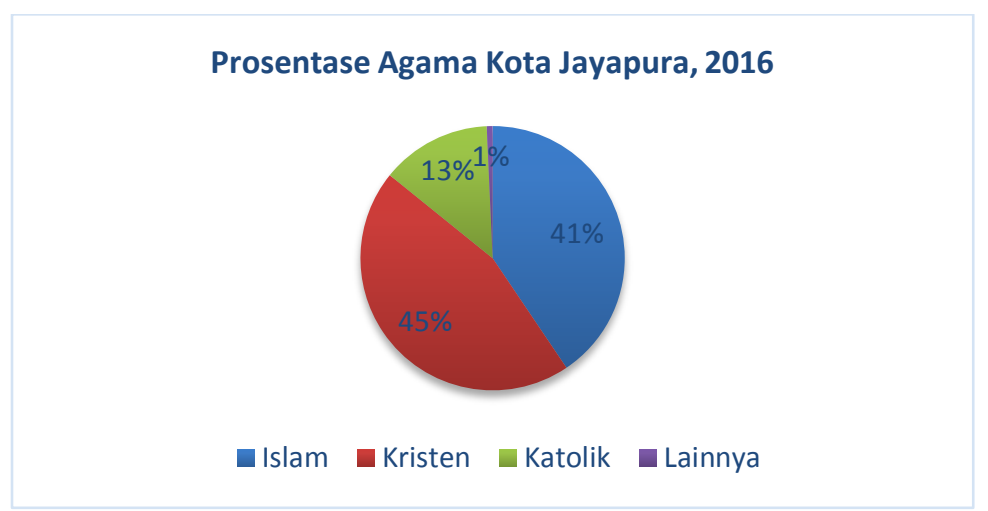

Gambar 1 Prosentase Agama Kota Jayapura tahun 2016

Sumber: Kota Jayapura Dalam Angka 2016 diolah oleh Peneliti

Mencermati komposisi penduduk berdasarkan agama sebagaimana yang ditampilkan pada gambar 1 di atas, dapat diketahui bahwa selisih jumlah khususnya antara Islam (41\%) dan Protestan (45\%) tidak terlalu jauh. Akan tetapi, jika dihubungkan dengan tingkat keterwakilan Muslim di birokrasi pemerintahan tidak menunjukkan adanya keterwakilan bagi Muslim secara proporsional. Secara umum, para pejabat yang menduduki jabatan strategis di beberapa SKPD di Kota Jayapura didominasi oleh orang asli Papua dan beragama Kristen. Berdasarkan data SKPD yang ada, dari 43 pejabat setingkat kepala dinas, hanya 6 (enam) orang atau 14\% yang beragama Islam (Muslim) seperti yang tergambar pada gambar berikut.

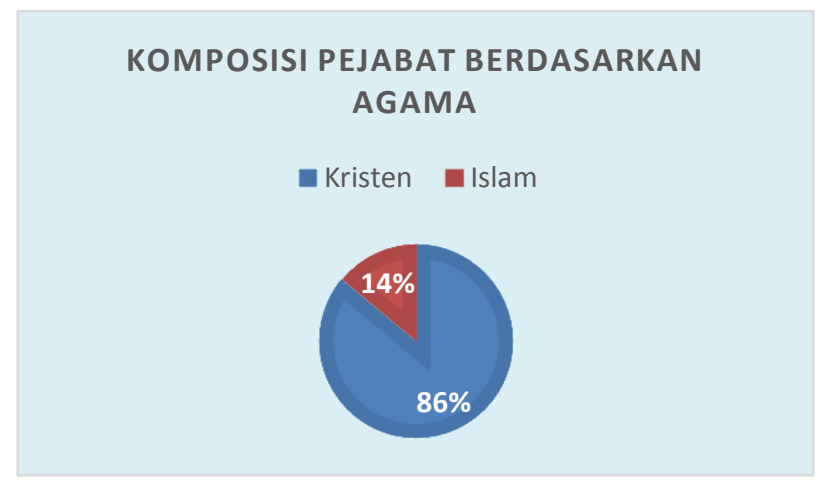

Gambar 2. Komposisi Pejabat Berdasarkan Agama Sumber: Data BKD diolah peneliti, 2016. 
Gambar tersebut di atas memperlihatkan peta umum jabatan di sejumlah SKPD di Kota Jayapura yang didominasi oleh orang asli Papua. Kondisi ini sesungguhnya dapat dikatakan sebagai sebuah kelaziman karena praktik seperti ini juga dapat ditemukan di berbagai tempat. Kultur mayoritas selalu menjadi mayoritas (penguasa) di Indonesia. Akan tetapi, yang membedakan fenomena di atas dengan apa yang terjadi dan dipraktikkan di tempat-tempat lain adalah "skala prioritas" penentuan pejabat birokrasi yang mengarah pada 'pengarus-utamaan" Kristen sebagai basis kebijakan. Kondisi Muslim yang sesungguhnya secara kuantitas dapat menjadi jalan untuk lebih terlibat dalam birokrasi pemerintah Kota Jayapura, sepertinya tidak dipertimbangkan. Persoalan inilah yang didiskusikan dalam tulisan ini, artinya mengapa keterwakilan Muslim tidak terwujud pada birokrasi pemerintahan Kota Jayapura. Ada tiga alasan mengapa hal tersebut terjadi, pertama, kebijakan otonomi khusus; kedua, pengaruh agama; dan ketiga, keengganan kelompok Muslim terlibat dalam politik. Akan tetapi, dalam tulisan ini penulis hanya menguraikan alasan pertama dan alasan yang kedua.

\section{A. Otonomi Khusus dan Dampaknya terhadap Muslim}

Pemberlakuan Otonomi Khusus (Otsus) bagi Provinsi Papua sebagaimana diatur dalam Undang-undang No. 21/ Tahun 2001 sedikit banyak telah dapat menjadikan obat penenang bagi masyarakat Papua. Selama hampir 27 tahun, sejak Pepera diadakan PBB, masyarakat Papua hidup dalam tekanan dari kekangan pemerintah pusat yang menggunakan pendekatan keamanan dalam menjaga integrasi wilayah yang penuh sumber daya alam tersebut. Semasa pemerintahan Presiden Abdurahman Wahid, rancangan UU Otonomi khusus Papua digodog, dan ketika masa Presiden Megawati undang-undang itu disahkan, meskipun pada kenyataannya implementasi di lapangan masih belum maksimal.

Sejak diberlakukannya UU No. 21 Tahun 2001 tentang Otonomi Khusus Provinsi Papua (Otsus) dan UU No. 35 Tahun 2008 sebagai kebijakan pemberlakuan khusus (affirmative action policy) bagi orang asli Papua, semakin menghidupkan jargon "Menjadi Tuan di Tanah Sendiri" bagi orang asli Papua sehubungan dengan pemberian kewenangan yang lebih kepada Papua untuk 
mengatur pemerintahan sendiri berdasarkan peraturan perundangan. Lahirnya Otsus di Papua tidak hanya berdampak pada adanya pengakuan terhadap identitas ataupun jati diri orang asli Papua, undang-undang ini juga mengandung sejumlah prinsip penting mengenai Papua dan orang-orang asli Papua yang belum pernah ditegaskan sebelumnya dalam suatu undang-undang Negara Republik Indonesia.

Otonomi khusus telah memberikan peluang dan kesempatan sebesarbesarnya bagi orang Papau tidak hanya untuk tampil dengan identitasnya, tetapi juga menjadi penentu kebijakan di Papua khususnya di Kota Jayapura. Dalam konteks tulisan ini, praktik penentuan pejabat sebelumnya menganut sistem 'dropdropan' karena pejabat menjadi kewenangan pemerintah pusat. Pasca otonomi khusus, kesempatan luas pun diperoleh dan diimplementasikan ke dalam seluruh aspek kehidupan, termasuk penentuan jabatan strategis di lingkungan pemerintahan. Meskipun otonomi khusus tidak mengatur mengenai keharusan orang Papua menjadi walikota dan bupati, namun 'tafsir' terhadap otonomi khusus juga diberlakukan bagi pemerintahan di tingkat kota dan kabupaten di seluruh wilayah Papua. Hal ini tentu saja diberlakukan untuk jabatan di level selanjutnya.

Selain mengandung sejumlah prinsip penting mengenai Papua dan Orang Asli Papua, UU Otsus ini berpedoman padanilai-nilai dasar yang bersumber dari adat istiadat rakyat Papua, nasionalisme yang bertumpu pada prinsip-prinsip kemanusiaan universal, dan penghormatan akan demokrasi dan hak-hak azasi manusia. Salah satu butir dari tujuh butir nilai dasar Otsus adalah "perlindungan terhadap hak-hak dasar penduduk asli Papua, yang dimaksudkan untuk memungkinkan masyarakat Papua agar dapat mengembangkan kemampuan diri yang dikaruniakan kepada Tuhan kepadanya secara baik dan bermartabat, sehingga dalam waktu secepat-cepatnya rakyat Papua dapat menjadi warga negara Indonesia dan anggota masyarakat dunia yang modern dan sejajar dengan bangsabangsa maju mana pun dengan tidak meninggalkan identitas dan jati dirinya. Pada saat yang sama, perlindungan akan hak-hak dasar dimaksud tidak dapat dipisahkan dari kewajiban-kewajiban yang melekat pada Orang Asli Papua, bahkan 
seluruh penduduk Papua, sebagai makhluk ciptaan Tuhan, warga masyarakat dan warga negara". 4

Undang-Undang No. 21 Tahun 2001 melahirkan adanya pemberian kewenangan khusus bagi penyelenggaraan pemerintah yang lebih merepresentasikan orang asli Papua baik di birokrasi pemerintahan maupun adanya lembaga Majelis Rakyat Papua (MRP) sebagai lembaga politik sekaligus sebagai lembaga kultural guna memberikan perlindungan hak-hak orang asli Papua. MRP sendiri dipilih mewakili beberapa unsur seperti adat, agama, dan perempuan. Pada tahun 2017 ini, anggota MRP sebanyak 51 orang. Keterwakilan dari unsur agama sebanyak 17 orang; dari unsur adat sebanyak 17 orang; dan dari unsur perempuan sebanyak 16 orang. Hal yang menjadi sorotan peneliti di sini adalah keterwakilan berdasarkan agama, di mana Islam hanya diwakili oleh 1 (satu) orang. ${ }^{5}$

Dalam prosesnya, otsus ini kemudian dibelokkan substansinya ke dalam bentuk 'papuanisasi' oleh oknum-oknum elit di tanah Papua. Menurut Beny Gia, ${ }^{6}$ sebagaimana dikutip oleh Cahyo Pamungkas $^{7}$ bahwa papuanisasi telah berlangsung sejak Zaman Belanda antara lain melalui: Pidato Perdana Menteri Dress yang mengakui hak kemerdekaan rakyat Papua tahun 1951, pemberian ijin pulang bagi orang Papua ke Papua dan orang non-Papua keluar Papua pada tahun 1940-an, pendirian sekolah pamomg praja di Kota Nicca Kampung Harapan pada 1946, pengiriman mahasiswa Papua ke luar negeri pada 1956-1960, Kongres Rakyat Papua I, 19 Oktober 1961, Konferensi untuk mempersiapkan kemerdekaan

\footnotetext{
${ }^{4}$ Agus Sumule. Mencari Jalan Tengah: Otonomi Khusus Provinsi Papua. Jakarta: Gramedia Pustaka Utama, 2003. h. 52-60.

${ }^{5}$ Unsur Muslim/Islam diwakili oleh Tony V.M Wanggai. Saat ini, ia sekaligus sebagai Ketua Pengurus NU Propinsi Papua. Dari sini juga dapat dilihat bagaimana dominasi salah satu kelompok agama di Papua. Sebab, pemilihan anggota MRP lebih didominasi oleh adat sehingga apapun agamanya, pada akhirnya juga dihubungkan dengan persoalan etnis/adat. Islam memang tidak memiliki akar kuat pada adat, kecuali Muslim di Lembah Baliem saja.

${ }^{6}$ Rev. Benny Giay. Menuju Papua Baru: Beberapa Pokok Pikiran sekitar Emansipasi Orang Papua, Seri Deiyai II. Jayapura: Deiyai-Elsham, 2001. h. 83-88.

${ }^{7}$ Cahyo Pamungkas. "Mencari Akar Permasalahan Konflik Agama di Papua", Jurnal Demokrasi dan HAM, Vol. 8, No. 2, 2008, h. 62-81. Lihat juga, Cahyo Pamungkas "The Representation of Religious Identity in Papua: Indonesia-ness and Papua-ness", International Indonesia Forum, Working Paper Series 8, 2014.
} 
Papua di Hollandia Maret 1960, dan peresmian New Guinea Raad pada 1 Desember 1961.

Istilah papuanisasi ini dengan menekankan status Otsus yang dimilikinya, struktur birokrasi dan jabatan politik, baik jabatan sipil maupun militer, secara bertahap menjadi dipegang oleh orang-orang Papua asli. ${ }^{8}$ Papuanisasi dalam arti sebenarnya adalah suatu proses di mana orang Papua menjadi dirinya sendiri, menjadi subjek, menjadi aktor dan belajar untuk menata masa depannya sendiri secara demokratis dengan mempertimbangkan seluruh unsur suku dan kepentingan di Tanah Papua. ${ }^{9}$ Dengan kata lain, Papuanisasi adalah suatu strategi dan upaya mengembalikan kemerdekaan ekonomi, politik, sosial budaya serta agama kepada orang Papua sebagai subjek. Gagasan ini berangkat dari pengalaman bahwa interaksi dengan kebudayaan non-Papua telah menyebabkan orang Papua tercerabut dari akar budaya dan agamanya. ${ }^{10}$ Upaya ini sekaligus menunjukkan bahwa orang Papua melakukan 'perlawanan' atas segala kebijakan pemerintah pusat selama ini. Kebijakan itu sendiri membawa implikasi pada keterpinggiran orang Papua secara struktural selama puluhan tahun.

Papuanisasi dimaknai sebagai rekognisi orang Papua asli yang didefinisikan sebagai proses sosial yang agenda-agendanya berpihak dan difokuskan pada orang Papua sekaligus dengan jati dirinya. ${ }^{11}$ Di dalamnya tercakup suatu strategi sosial politik afirmatif yang bertujuan membantu orang Papua dalam melindungi dan mengembangkan sumber daya yang dimilikinya sehingga orang Papua mampu bernegosiasi dan memiliki daya tawar yang memadai dalam proses perubahan sosial yang cepat serta mengambil keuntungan yang adil untuk keberlangsungan hidupnya dan kesejahteraannya.

\section{B. Rekrutmen Berbasis Identitas Primordial}

8 Hargyaning Tyas. Studi kebijakan pertahanan: problematika pengelolaan keamanan dan pertahanan di wilayah konflik, Aceh dan Papua. Jakarta: LIPI, 2007.

${ }_{9}$ Rev. Benny Giay. Menuju Papua Baru: Beberapa Pokok Pikiran sekitar Emansipasi Orang Papua, Seri Deiyai II. Jayapura: Deiyai-Elsham, 2001. h. 27.

${ }^{10}$ Ibid,. h. 81.

${ }^{11}$ Muridan S. Widjojo. Papua Road Map: Negotiating the Past, Improving the Present, and Securing the Future. Jakarta: Yayasan Obor-LIPI-TIFA, 2009. h. 10. Lihat juga, Cahyo Pamungkas. "Mencari Akar Permasalahan Konflik Agama di Papua", Jurnal Demokrasi dan HAM, Vol. 8, No. 2, 2008, h. 65. 
Dalam persoalan birokrasi, banyak fakta menunjukkan bahwa dalam praktik penempatan jabatan masih didominasi oleh pemenuhan kebutuhan kelompok masyarakat dan agama tertentu memungkinkan adanya tindakan yang mengarah pada marginalisasi dan diskriminasi terhadap kelompok yang lain khususnya Muslim. ${ }^{12}$ Porsi bagi Muslim dalam praktiknya sangat sedikit, meskipun akhir-akhir ini selalu dimunculkan wacana keterwakilan dari kelompok Muslim, khususnya dalam kepentingan pencalonan Walikota dan Wakil Walikota Jayapura yang disuarakan oleh kelompok Muslim seperti Majelis Muslim Papua. Wacana seperti ini semakin mencuak menjelang pemilihan kepala daerah (pilkada) sebagai wujud politik affirmasi terhadap kelompok-kelompok (agama) yang ada.

Anggapan bahwa tanah Papua adalah Tanah Injil merupakan diskursus yang cukup lama berkembang. Hal ini diawali oleh misi penginjilan di tanah papua. Para penyebar injil inilah yang merekonstruksi nalar orang Papua, bahwa Papua merupakan tanah 'untuk orang-orang Kristen'. Pada ranah politik dan keagamaan di Tanah Papua, agama Kristen mendapat pengakuan sebagai agama orang Papua asli. Pengakuan ini tidak bersifat taken for granted, tetapi dibentuk melalui diskursus Gereja Kristen dan proses sosial. Para misi zending memiliki peran dalam memproduksi pengetahuan tentang identitas orang Papua. Hal ini dapat dimengerti mengingat peranan gereja adalah memperkenalkan orang Papua dengan pengetahuan modern sehingga mereka mengenal jati dirinya. ${ }^{13}$

Dalam beberapa keterangan yang diperoleh, praktik penentuan jabatan di lingkungan birokrasi lebih didasarkan pada kepentingan etnis kelompok yang berkuasa. OW (35), salah seorang informan, membenarkan terjadinya praktik tersebut. Ia mengatakan bahwa:

"Yang lebih dominan dalam penentuan jabatan di Jayapura bukanlah semata agama, tetapi lebih pada kesamaan suku. Siapa pun walikotanya, pasti akan memasang orang-orangnya di sekelilingnya. Mereka melakukan hal tersebut karena ketika orang lain yang berkuasa juga melakukan hal serupa terhadap kelompok etnis lain" (Wawancara, 11 Februari, 2016 di Jayapura).

12 Idrus Al Hamid. Jalan Panjang Perdamaian Papua: Sejarah dan Peradaban. Yogyakarta: The Phinisi Press, 2017.

13 S. Rizzo. "From Paradise Lost to Promised Land: Christianity and the Rise of West Papua". P.hD Thesis. Australia: University of Wollongong, 2004. 
Tidak jauh berbeda dengan pernyataan informan tersebut, salah seorang pejabat (Muslim) di Kota Jayapura secara tidak langsung membenarkan hal tersebut. Ia mengatakan bahwa:

"Siapapun yang naik menjadi walikota, maka akan menggunakan orangorangnya untuk membantunya dalam menjalankan tugasnya. Adapun wakilnya hanya menjadi pelengkap karena perannya juga tidak banyak, misalnya hanya membuka acara-acara sosial dan lain-lain" (AI, 56, Wawancara di Jayapura, 23 Oktober 2016).

Penjelasan di atas memberikan petunjuk atas terjadinya praktik pengangkatan pejabat berdasarkan kesamaan etnis. Faktor etnisitas menjadi hal yang sangat penting. Adapun agama tidak terlalu berpengaruh secara langsung, namun tetap ada pengaruhnya. Ketika walikota berasal dari etnis pegunungan, maka dapat dipastikan bahwa mayoritas pejabat di berbagai SKPD atau dinas berasal dari etnis pegunungan. Sebaliknya, ketika Walikota berasal dari etnis di wilayah pantai atau pesisir, maka yang diangkat pun berasal dari etnis di wilayahwilayah pantai, terlepas dari apakah ia Kristen atau bukan. Akan tetapi, fakta juga menunjukkan bahwa mayoritas pejabat yang diangkat walikota memang beragama Kristen (Protestan). Dengan demikian, dapat dikatakan bahwa etnis dan agama berkontibusi penting dalam hubungannya dengan penentuan pejabat di lingkungan pemerintah kota Jayapura.

Dari data tersebut dapat dilihat bahwa keterwakilan Muslim dalam birokrasi sangat timpang. Sebab, dari 43 SKPD Kota Jayapura, hanya 6 orang termasuk wakil walikota yang berasal dari Muslim. Di sinilah titik persoalannya, dalam hal ini keterwakilan Muslim sangat jauh dari keterwakilan Kristen (Papua). Sebagaimana yang telah disinggung di muka, ada banyak faktor yang menyebabkan hal tersebut terjadi. Salah satu faktor yang paling mengemuka adalah status bagi Muslim yang masih diposisikan sebagai pendatang. Sebagai pendatang, bagi umumnya penduduk Papua, tidak memiliki 'hak' yang sama dengan non-pendatang, termasuk dalam penempatan jabatan seperti di lingkungan pemerintahan kota. 
Selama ini berkembang sistem rekrutmen pegawai lebih didasarkan atas pertimbangan etnis. Riset Agus Dwiyanto ${ }^{14}$ memperlihatkan menguatnya pertimbangan etnis dalam proses rekrutmen pegawai. Terlebih lagi jika nama etnis (marga) tersebut dikaitkan dengan persoalan "jaringan" dengan pejabat penting pemerintah daerah yang kebetulan juga berasal dari etnis atau marga yang sama. Fakta-fakta ini terjadi di hampir seluruh kabupaten/kota di seluruh Indonesia. Kasus di Kota Jayapura semakin meneguhkan argumentasi ini. Hal ini juga menunjukkan bahwa pada kondisi tertentu, ikatan kesamaan etnis mampu mempengaruhi kebijakan, termasuk pengangkatan pejabat di lingkup sebuah pemerintahan.

Selain identitas etnis, identitas keagaman juga sangat diperhitungkan di dalam pola rekrutmen pejabat dan pegawai, khususnya di pemerintah Kota Jayapura. Berdasarkan penelitian yang telah dilakukan, sangat tampak 'papuanisasi' dan 'protestanisasi' di dalam proses rekrutmen pegawai dan pejabat di pemerintah Kota Jayapura. Dalam wawancara dengan salah seorang informan, terungkap bahwa para pegawai dan pejabat non-Muslim, khususnya yang beragama Kristen Protestan sangat mudah mendapatkan apresiasi dari pimpinan daerah Kota Jayapura. Hal ini dimungkinkan oleh latar belakang agama dan etnis walikota saat ini. Meskipun wakil walikota Jayapura berlatar belakang etnis Bugis dan Muslim, tetapi tidak terlalu memainkan peran penting di dalam rekrutmen pegawai dan penentuan jabatan di SKPD. Dalam konteks ini, wakil walikota tidak memiliki peran dan wewenang yang cukup siginifikan di dalam eksekusi setiap kebijakan walikota.

Terkait dengan hal di atas, FS (43) mengemukakan bahwa:

Karena agama, banyak yang tidak sejalan dengan keinginan orang banyak. Orang Islam hanya diwakili oleh beberapa orang di SKPD, padahal jumlah penduduk Islamnya tidak jauh beda dengan Kristen Protestan di Jayapura (Wawancara, di Jayapura 12 Desember 2017).

Hal lain yang terungkap di dalam penelitian ini adalah penuturan informan, bahwa di sejumlah SKPD yang kepala dinasnya non-Muslim, prosentase pegawai di SKPD tersebut sangat minim. Sementara di SKPD yang kepala dinasnya seorang Muslim,

14 Agus Dwiyanto. Mengembalikan Kepercayaan Publik Melalui Reformasi Birokrasi. Jakarta: Gramedia Pustaka Utama, 2003. h. 144. 
maka prosentase pegawai Muslim cukup banyak. Di SKPD yang kepala dinasnya Kristen, pegawai-pegawai yang berlatarbelakang Muslim tidak memegang peran penting di dalam pengambilan kebijakan. Pegawai-pegawai dengan latar belakang beragama Islam kebanyakan hanya berfungsi sebagai eksekusi kebijakan di lapangan. Berbeda halnya dengan SKPD yang kepala dinasnya seorang Muslim, selain memegang peran penting di dalam pengambilan kebijakan, pada saat yang sama juga turut menjadi eksekutor kebijakan di lapangan.

Bahkan, sebagaimana penjelasan gambar 2 dari 6 (enam) pejabat dari kalangan Muslim tidak ada satu pun dari mereka yang berasal dari Muslim Papau (asli). Jadi, kesulitan bagi Muslim memiliki relevansi dengan argumen bahwa faktor agama berperan dalam penentuan jabatan di lingkungan birokrasi di Kota Jayapura. Artinya, diskriminasi yang terjadi sangat kompleks karena selain melibatkan agama, juga ada 'sentimen' terhadap sesama orang Papua. Pejabat Muslim yang ada saat ini berasal dari Jawa, Sulawesi, dan Maluku. Adapun pejabat lain (beragama Kristen) selain berasal dari Papua, juga ada yang berasal dari Maluku, Sulawesi, Sumatera, dan Bali. Beberapa daerah yang disebutkan ini dikenal sebagai daerah di mana tradisi ke-Kristen-annya cukup kuat.

Kondisi birokrasi seperti ini memperlihatkan persaingan yang tidak sehat sehingga akan membuat birokrasi tidak beroperasi secara prosesional di dalam pelayanan kepada publik di Kota Jayapura. Salah seorang informan menuturkan kepada peneliti, bahwa cara kerja atau kinerja birokrasi yang dipraktekkan di pemerintah Kota Jayapura sesungguhnya bukan cara kerja birokrasi modern, meskipun saat ini kewenangan ada di tangan pemerintah daerah (desentralisasi). AM (52) menegaskan bahwa "otonomi daerah merupakan jawaban pada pengeloaan negara yang sentralistik sebelumnya". Akan tetapi, di tingkat praktik masih banyak masalah. Kebijakan SKPD akan cenderung diskriminatif dan pasti akan menimbulkan ketidakpuasan publik di Kota Jayapura.

Pola rekrutmen pegawai dan pejabat yang memiliki kesamaan latar belakang agama dan etnis dengan walikota, di satu sisi dapat dianggap positif, sebab walikota akan dapat mengendalikan pegawai dan pejabatnya, dan pada saat yang sama akan mendapatkan loyalitas dari pegawai dan pejabat tersebut. Akan 
tetapi, di saat yang sama, justru akan menciptakan ketidakadilan, menurunnya kinerja pegawai di birokrasi, dan pegawai serta pejabat tidak bekerja secara professional. Persoalan berikutnya yang dapat terjadi jika praktik rekrutmen bercorak seperti ini adalah hilangnya kepercayaan publik terhadap pemerintah. Jika hal ini terjadi, tentu saja akan berpengaruh langsung pada kualitas pemerintahan.

Selain kesamaan agama, ada beberapa pertimbagan yang dijadikan patokan menentukan pejabat di pemerintahan Kota Jayapura. Hal ini terungkap dalam beberapa pernyataan informan yang ditemui selama penelitian ini dilakukan. AK (56) misalnya menempatkan aspek nilai tawar politik sebagai alasan walikota memilih pembantunya. Ia mengatakan bahwa:

... penempatan posisioning seperti yang terjadi sekarang ini, itu tidak murni melihat persoalan ketidak-mampuan seseorang tapi ada bargaining politik, posisi politik orang sangat penting karena juga untuk kepentingan selanjutnya...(Wawancara, Jayapura, 03 Januari 2018).

Informan lain juga mengatakan hal berbeda. Penentuan jabatan di lingkungan pemerintahan kota lebih didasarkan pada persoalan kepentingan jangka Panjang. OW (38) dengan tegas mengatakan bahwa agama hanya aspek lain seseorang tidak dipilih menjabat, ia lebih jauh mengatakan:

... ini soal ke depan, orang berpolitik bicara soal jangka panjang, investasi dia ke depan sehingga orang-orang yang membantu dia waktu dia dipilih calon itu yang akan dipertimbangkan di posisi-posisi itu, kalau kemudian dia Islam, mungkin itu hanya kebetulan... (Wawancara, Jayapura 03 Januari 2018).

Artinya, ia tidak melihat agama sebagai faktor penting di sini, tetapi kepentinganlah yang menurutnya lebih mendasari mengapa seseorang ditempatkan pada posisi strategis (pejabat). Dengan demikian, agama khususnya Islam tidak diperhitungkan di sini.

Lain halnya dengan pernyataan PY (42) mengenai komposisi pejabat yang didominasi oleh kelompok (agama) tertentu. Kondisi keterbukaan bahkan kebebasan Papua pasca era Reformasi menyebabkan banyak perubahan mendasar terjadi, termasuk praktik penempatan jabatan di level propinsi dan kabupaten/kota. Otonomi Khusus Papua telah mengubah banyak hal. 
Keterkungkungan orang-orang Papua sebelumnya tiba-tiba lepas di era Reformasi. Hanya saja kondisi ini pula yang menyebabkan perubahan terjadi tidak terkontrol dengan baik. Ia menegaskan bahwa:

... dengan euphoria otsus jadi orang Papua terkhusus diberikan keleluasaan yang cukup secara politik...(Wawancara, Jayapura 03 Januari 2018).

Selain euphoria tadi, PY juga mengatakan bahwa faktor 'kesadaran diri' orang Islam juga turut menyebabkan mengapa komposisi pejabat timpang di Papua khususnya di Kota Jayapura. Masih dalam waktu yang sama ia menceritakan pengalaman pribadinya di lingkungan tempat tinggalnya.

...kebetulan saya tinggal di lingkungan di Papua dan saya anggap sebagai minoritas sehingga kita mau maju ke permukaan harus hati-hati, menjadi pemimpin harus hati-hati. Ketika saya ditawari menjadi ketua RT mereka melihat saya bukan sebagai orang Muslim tetapi karena mereka lihat saya bagaimana nilai-nilai Islam yang saya terapkan dalam lingkungan saya. Saya sendiri Islam, ketika mereka saya menunjuk menjadi ketua RT saya tidak mau, beban ini terlalu berat. Pertama saya minoritas di sini ... (wawancara, Jayapura, 03 Januari 2018).

Pernyataan PY di atas dapat dilihat sebagai sebuah bentuk kesadaran atas kondisi sosial yang dihadapi. Tentu saja, jika melihat lebih jauh, PY sesungguhnya menginginkan kelompok mayoritas menjadi pemimpin di lingkungannya. Hal ini juga terkait dengan kuatnya pengaruh otonomi khusus yang memang diperuntukkan bagi orang Papua. Otonomi khusus memberikan prioritas kepada orang Papua. ${ }^{15}$

Menyimak pernyataan informan-informan tersebut, tampak bahwa persoalan keterwakilan Muslim di pemerintahan Kota Jayapura dipengaruhi beberapa hal. Pertama, kuatnya posisi tawar kelompok tertentu. Artinya, kelompok Muslim tidak memiliki posisi yang kuat baik secara politik maupun ekonomis sehingga ia ditinggalkan. Kedua, kepentingan jangka panjang. Penempatan seorang pejabat oleh walikota disebabkan oleh prediksi masa depan. Penentuan pejabat

${ }^{15}$ Habel Suwae. Identitas Cair Papua. Yogyakarta: Kanisius, 2013. h. 86. 
dimaksudkan untuk mendukung (walikota) untuk kepentingan berikutnya. Ketiga, kondisi kebebasan Papua khususnya pasca Orde Baru. Euphoria yang dilengkapi dengan otsus telah mengubah wajah Papua secara drastis. Kesempatan ini pun dimanfaatkan oleh orang Papua untuk menjadi 'tuan rumah' di negerinya sendiri. Keempat, persoalan atau sentimen agama. Faktor ini bagi informan juga berperan dalam memilih pejabat di pemerintahan Kota Jayapura. Bagi penulis, kondisi tersebut menunjukkan terjadinya persaingan di antara agama khususnya Islam dengan Kristen, ${ }^{16}$ termasuk dalam penentuan pejabat.

Dalam konteks Kota Jayapura, anggapan ini juga cukup berkembang secara massif dan berkelindan dengan persoalan birokrasi pemerintahan di Kota Jayapura. Dalam sebuah kesempatan, seorang tokoh agama Islam di Jayapura mengungkapkan:

Di sini ada asumsi bahwa orang Papualah yang berhak untuk segalagalanya. Jadi jangan heran jika dalam pejabat pemerintah kota orang Muslim hanya sedikit. Kalau diperhatikan memang tidak ada aturan tertulis mengenai hanya orang Papua yang berhak menjadi pejabat di Jayapura, tapi dalam praktiknya itu terjadi (Wawancara, PRT (65), 02 Mei 2017 di Jayapura).

Bahkan, masih menurut informan, ada semacam penegasan bahwa di struktur terdapat empat tipologi calon pejabat. Pertama, orang Papua (asli) dan beragama Kristen. Golongan ini yang paling banyak menduduki posisi penting di seluruh Papua saat ini. Kedua, orang pendatang dan beragama Kristen. Golongan banyak berasal dari pendatang dari berbagai wilayah Indonesi yang mayoritas Kristen seperti Minahasa, Batak, dan Toraja. Mereka saat ini juga banyak menduduki posisi penting di pemerintahan. Ketiga, orang pendatang dan beragama Islam. Golongan ini umumnya menguasai sentra ekonomi dan memiliki kesempatan dan peluang untuk masuk dalam birokrasi karena memiliki modal ekonomi yang cukup kuat. Keempat, orang Papua (asli) dan beragama Islam (Muslim Papua). Selengkapnya, mengenai hal ini dapat dilihat pada gambar 3 berikut.

\footnotetext{
${ }^{16}$ Hasse Jubba. Kontestasi Identitas Agama: Spiritual dan Lokalitas di Indonesia. Yogyakarta: The Phinisi Press, 2018.
} 


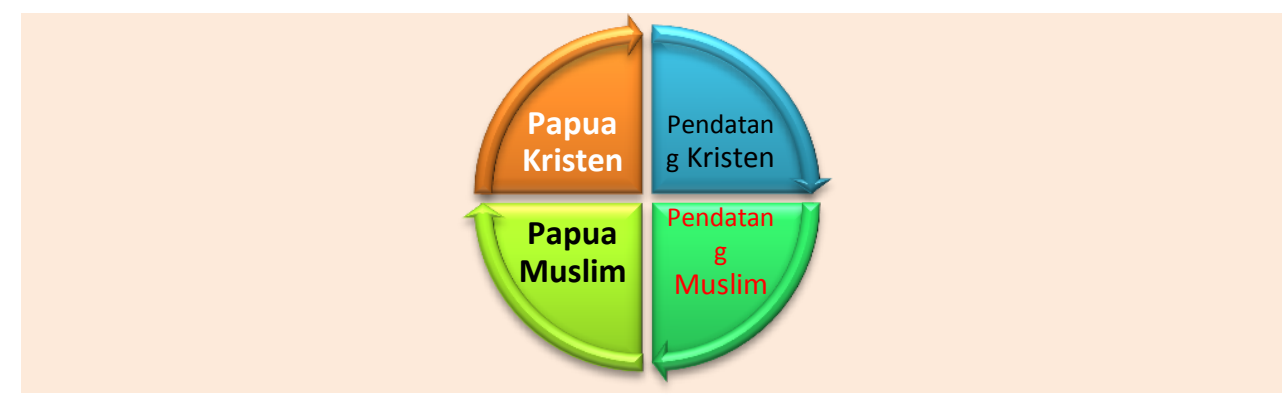

Gambar 3 Tipologi Masyarakat Papua

Sumber: Hasil Wawancara, diolah peneliti, 2017.

Golongan keempat (Papua Muslim) inilah yang termasuk minoritas dalam struktur pemerintahan. Sebab, mereka selain harus bersaing dengan orang Papua asli (nonMuslim), juga harus berkompetisi dengan para pendatang yang Muslim.

Masih menurut informan, sebenarnya Muslim di Papua bukanlah pendatang atau Islam bukan agama yang datang belakangan. Ia menegeaskan bahwa:

"Sesungguhnya kita bukan Muslim pendatang. Islam bukan pendatang. Islam punya hak yang sama dengan Kristen. Islam dalam sejarahnya dari Raja Ampat. Makanya sejarah harus diluruskan" (Wawancara, PRT (65), 02 Mei 2017 di Jayapura).

Adapun fakta bahwa penguasaan beberapa sektor dikuasai oleh orang Muslim (pendatang), memang benar adanya dan bisa ditemukan di mana-mana di Kota Jayapura. Penguasaan sector ekonomi sangat tampak. Misalnya, pusat perbelanjaan/pertokoan umumnya dimiliki oleh pendatang dan etnis Cina. Menurut informan, mungkin Allah memberikan keahlian kepada mereka sehingga memiliki usaha yang demikian. Di pasar-pasar di Jayapura, bahkan hampir semuanya dikuasai pendatang. Hanya pasar mama-mama Papua yang memang didominasi oleh orang Papua. Melihat fakta tersebut, menurut informan, ada kekhawatiran bagi orang Papua terhadap keberhasilan orang luar. Mereka khawatir akan terpinggirkan. Di Papua terjadi demikian, meskipun di kota-kota lain juga demikian.

Jika melihat dan mengamati secara seksama pemetaan di atas (Gambar 3), sorotan utama yang perlu direspons adalah tipe masyarakat yang termasuk dalam katagori Papua Muslim. Sebab, meskipun orang-orang yang masuk dalam katagori 
ini merupakan orang asli, namun tetap saja tidak memiliki peran (yang strategis) di Papua khususnya di Kota Jayapura. Data mengenai komposisi pejabat yang diperoleh dari data BKD Kota Jayapura menunjukkan bahwa dari beberapa pejabat Muslim yang ada, tidak satu pun dari mereka yang berasal dari Papua Muslim. Ini artinya, Muslim memang menjadi salah satu faktor penyebab terjadinya misrepresentasi pejabat di pemerintahan Kota Jayapura.

\section{Kesimpulan}

Birokrasi pemerintahan di daerah memiliki relasi dengan masyarakat di mana birokrasi itu beroperasi. Pada gilirannya, seringkali birokrasi mengadopsi sistem nilai yang berkembang di masyarakat. Birokrasi di pemerintah Kota Jayapura tentu tidak luput dari realitas ini, bahwa proporsi orang asli Papua di birokrasi merupakan sesuatu yang berjalan baik secara alamiah maupun disengaja. Hal ini merupakan salah satu konsekuensi dari otonomi daerah dan otonomi khusus yang diberlakukan di Papua, khususnya di Kota Jayapura. Otonomi daerah dan otonomi khusus telah memberikan peluang yang lebih besar bagi orang asli Papua untuk terlibat dan menduduki jabatan-jabatan strategis di lingkungan birokrasi seperti SKPD di berbagai level (propinsi dan kabupaten/kota).

Persoalan etnis menjadi faktor yang cukup dominan di dalam birokrasi di Kota Jayapura. Hal ini telah menjadi kelaziman dari setiap birokrasi di daerah. Jika walikota berasal dari latarbelakang etnis dan klan tertentu, maka pada gilirannya etnis dan klan itu otomatis juga akan turut menjadi bagian dari birokrasi. Selain itu, temuan peneliti juga menempatkan sentimen agama sebagai faktor yang juga berpengaruh terhadap keterwakilan Muslim di pemerintahan Kota Jayapura. Artinya, identitas keagamaan juga turut memainkan peran penting dalam operasi birokrasi di Kota Jayapura. Meskipun sulit diketemukan secara gamblang agama akan sangat memberi pengaruh di dalam pengambilan kebijakan yang berhubungan dengan masyarakat, namun dalam penentuan pejabat di SKPD identitas keagamaan menjadi salah satu preferensi di dalam penentuan pejabat untuk jabatan tertentu di SKPD di Kota Jayapura. Berdasarkan temuan penelitian, proporsi atau representasi orang Muslim di birokrasi pemerintah Kota Jayapura sangat minim. Sejumlah jabatan SKPD di Kota Jayapura didominasi oleh pejabat 
dengan identitas keagamaan Kristen. Sementara pejabat Muslim hanya menduduki beberapa SKPD di Kota Jayapura.

Identitas keagamaan tertentu yang turut memainkan peran penting dalam penentuan jabatan di Kota Jayapura merupakan persoalan tersendiri mengingat justifikasinya sulit ditemukan. Prosentase pemeluk Kristen Protestan di Kota Jayapura cukup besar ketimbang prosentase pemeluk agama lain adalah salah satu alasan yang dapat dijadikan rujukan terhadap praktik tersebut. Hal ini pada gilirannya akan berimplikasi pada semua sektor kehidupan, termasuk di birokrasi. Di lihat dari satu sudut pandang yang pasti, perimbangan pejabat Protestan dan Muslim hanya akan menciptakan sentimen agama, baik di birokrasi itu sendiri maupun di masyarakat kota Jayapura. Dalam konteks ini, proporsi jabatan di SKPD yang didominasi oleh pejabat Kristen justeru akan membuat birokasi di Kota Jayapura beroperasi dengan baik dalam rangka memberi pelayanan kepada publik di wilayah ini. Oleh karena itu, istilah mayoritas dan minoritas acapkali tidak tepat dipergunakan dalma konteks birokrasi di Kota Jayapura.

Hal-hal yang disebutkan di atas memperlihatkan bahwa kerapkali agama memainkan peran penting di dalam operasi kekuasaan, baik pada tingkatan nasional maupun di daerah. Agama dan kekuasaan (baca: birokrasi) seringkali bekerjasama dalam operasi pemerintahan di daerah. Hal lain yang tampak adalah elit dan institusi keagamaan menjadi bagian penting di dalam sistem operasi birokrasi di daerah. Meskipun tidak jelas hubungan resmi antara elit dan institusi keagamaan dengan birokrasi, tetapi secara tidak kasat mata elite dan institusi keagamaan turut memainkan peran penting, jika bukan menentukan, dalam posisiposisi strategis di birokrasi. Kota Jayapura dengan prosentase pemeluk agama Kristen yang dominan, apalagi didukung oleh walikota yang Beragama Protestan, memiliki alasan jika persoalan agama menjadi salah satu preferensi dalam penentuan jabatan-jabatan strategis di SKPD.

Subordinasi Muslim di pemerintahan Kota Jayapura merupakan persoalan yang terjadi dan berlangsung hingga saat ini. Melalui proporsi dan pola rekrutmen pegawai yang relatif kecil untuk orang Muslim, maka hal ini akan memungkinkan kebijakan pemerintah kota tidak berpihak kepada masyarakat muslim di Kota 
Jayapura. Perimbangan jabatan dan pegawai di Kota Jayapura bukan solusi atas diskriminasi orang-orang Muslim di pemerintah kota Jayapura. Paling penting, setiap kebijakan pemerintah kota Jayapura tidak diskriminatif dan berpihak kepada realitas masyarakat Kota Jayapura yang heteregon dari aspek agama maupun etnis. Setiap kebijakan pemerintah kota Jayapura sejatinya tidak mendikotomikan antara pribumi dan non-pribumi, Kristen maupun non-kristen. Kebijakan pemerintah kota Jayapura yang apreasiatif terhadap heterogenitas agama dan etnis di Kota Jayapura pada gilirannya akan menciptakan semangat kebersamaan seluruh elemen masyarakat di Kota Jayapura.

\section{Daftar Pustaka}

Abbink, Jon. 2011. "Religion in Public Spaces: Emerging Muslim-Christian Polemics in Ethiopia", dalam Jurnal African Affairs, Vol. 110, No. 439 (April), Oxford: Oxford University Press. pp. 253-274.

Al Hamid, Idrus. 2017. Jalan Panjang Perdamaian Papua: Sejarah dan Peradaban. Yogyakarta: The Phinisi Press.

Ayorbaba, Anthonius. 2011. The Papua Way: Dinamika Konflik Laten dan Refleksi 10 Tahun Otsus Papua. Papua: Tabloid Perempuan Papua-The Papuan Institute and Institute for Indonesian Local Policy Studies (IIpos).

Dwiyanto, Agus. 2003. Mengembalikan Kepercayaan Publik Melalui Reformasi Birokrasi. Jakarta: Gramedia Pustaka Utama.

Giay, Rev. Benny. 2001. Menuju Papua Baru: Beberapa Pokok Pikiran sekitar Emansipasi Orang Papua, Seri Deiyai II. Jayapura: Deiyai-Elsham.

Indiyanto, Agus (ed.). 2013. Agama di Indonesia dalam Angka: Dinamika Demografis Berdasarkan Sensus Penduduk tahun 2000 dan 2010. Yogyakarta: CRCS UGM.

Jubba, Hasse. 2018. Kontestasi Identitas Agama: Lokalitas Spiritual di Indonesia. Yogyakarta: The Phinisi Press.

Pamungkas, Cahyo. 2008. "Mencari Akar Permasalahan Konflik Agama di Papua”, Jurnal Demokrasi dan HAM, Vol. 8, No. 2, 2008, h. 62-81.

Pamungkas, Cahyo. 2014. "The Representation of Religious Identity in Papua: Indonesia-ness and Papua-ness", International Indonesia Forum, Working Paper Series 8.

Rizzo, S. 2004. "From Paradise Lost to Promised Land: Christianity and the Rise of West Papua". P.hD Thesis. Australia: University of Wollongong.

Solossa, Yakobus Perviddya. 2005. Otsus Papua Mengangkat Martabat Rakyat Papua di dalam NKRI. Jakarta: Sinar Harapan. 
Sumule, Agus. 200. Mencari Jalan Tengah: Otonomi Khusus Provinsi Papua. Jakarta: Gramedia Pustaka Utama.

Suwae, Habel. 2013. Identitas Cair Papua. Yogyakarta: Kanisius.

Tyas, Hargyaning. 2007. Studi kebijakan pertahanan: problematika pengelolaan keamanan dan pertahanan di wilayah konflik, Aceh dan Papua. Jakarta: LIPI.

Widjojo, Muridan S. 2009. Papua Road Map: Negotiating the Past, Improving the Present, and Securing the Future. Jakarta: Yayasan Obor-LIPI-TIFA. 